\title{
Effects of Asian dust event particles on inflammation markers in peripheral blood and bronchoalveolar lavage in pulmonary hypertensive rats
}

\author{
Yu-Chen Lei, ${ }^{\mathrm{a}}$ Chang-Chuan Chan, ${ }^{\mathrm{b}}$ Peng-Yau Wang, ${ }^{\mathrm{c}}$ Chung-Te Lee, ${ }^{\mathrm{c}}$ \\ and Tsun-Jen Cheng ${ }^{\text {a,* }}$ \\ ${ }^{a}$ Institute of Occupational Medicine and Industrial Hygiene, College of Public Health, National Taiwan University, No. 1, \\ Ren-Ai Rd., Sec. 1, Taipei 10018, Taiwan \\ ${ }^{\mathrm{b}}$ Institute of Occupational Medicine and Industrial Hygiene, National Taiwan University, Taipei, Taiwan \\ ${ }^{\mathrm{c}}$ Institute of Environmental Engineering, National Central University, Chung Li, Taiwan \\ Received 24 February 2003; received in revised form 2 June 2003; accepted 24 June 2003
}

\begin{abstract}
The health impact of dust events from China has become a concern within China and in its neighboring countries. Previous epidemiological studies have demonstrated an association between particulate matter exposure and cardiopulmonary mortality. Here, we use pulmonary hypertensive rat models to examine inflammation markers in the lung and in peripheral blood after exposure to Asian dust storm particles. Using a nose-only inhalation system, eight pulmonary hypertensive rats were exposed to concentrated ambient particles (CAPs) from an actual Asian dust storm that took place between March 18 and 19, 2002; four control rats were also exposed to room air. Four rats exposed to CAPs of $315.6 \mu \mathrm{g} / \mathrm{m}^{3}$ for $6 \mathrm{~h}$ were classified as the low-exposure group, and another four rats exposed to CAPs of $684.5 \mu \mathrm{g} / \mathrm{m}^{3}$ for $4.5 \mathrm{~h}$ were classified as the high-exposure group. The animals were sacrificed $36 \mathrm{~h}$ after exposure. Inflammation markers in the peripheral blood and in the bronchoalveolar lavage (BAL) were analyzed, and IL-6 in BAL was also determined using ELISA. White blood cell counts in peripheral blood increased with increased CAP exposure levels $(P<0.001$, test for trend). In BAL analysis, total cell numbers and the proportion of neutrophil also increased with increased CAP levels $(P<0.001$, test for trend for both markers). Positive dose-response relationships between CAP exposure and total protein $(P<0.05)$ and between CAPs and LDH activity $(P<0.05)$ were also observed. Moreover, IL-6 protein in BAL increasing with CAP levels $(P<0.05$, test for trend) was demonstrated. Our results revealed that exposure to particulate matters during an Asian dust storm could increase lung inflammation and injury in pulmonary hypertensive rats. Further studies are needed to determine the components of dust storm particles that may contribute to the particle toxicity.
\end{abstract}

(C) 2003 Elsevier Inc. All rights reserved.

Keywords: Ambient particles; Concentrator; Pulmonary hypertension; Inflammation markers; Dust storm

\section{Introduction}

Particulate matters (PM) from dust storms that originate in the Mongolian region of China have raised concerns within China and in its neighboring countries (Taylor, 2002). Earlier epidemiological studies have shown that increased levels of ambient PM are associated with increased cardiopulmonary morbidity and mortality (Pope et al., 2002; Pope and Dockery, 1999; Samet et al., 2000). Since previous studies have

${ }^{*}$ Corresponding author. Fax: + 886-2-2395-7845.

E-mail address: tcheng@ha.mc.ntu.edu.tw (T.-J. Cheng). focused primarily on particles generated by combustion (Dreher et al., 1997), it is not clear whether particles from natural dust storms would also cause similar effects. A recent Korean study observed an increased mortality from respiratory and cardiovascular diseases in the elderly during Asian dust events (Kwon et al., 2002). However, the data concerning the health effects of dust event particles remain limited.

Animal models have been used in a number of studies on the effect of particles (Kodavanti et al., 1998). Several animal studies have reported an increase in inflammation markers in bronchoalveolar lavage (BAL) and in peripheral blood among pulmonary hypertensive 
rats after they were exposed to residual oil fly ash (ROFA) (Kodavanti et al., 1999) and to concentrated ambient particles (CAPs) (Gordon et al., 1998). In this study, pulmonary hypertensive rats were exposed to concentrated air PM generated by a particle concentrator during an actual dust storm. The rats were examined for inflammation markers in BAL and in peripheral blood.

\section{Materials and methods}

\subsection{Animals}

Male Sprague-Dawley rats (body weight of 300$350 \mathrm{~g}$ ) were obtained from the National Laboratory Animal Breeding and Research Center, Taiwan. They were housed in plastic cages on Aspen chip bedding and provided with Lab Diet 5001 and water ad libitum, except during exposure. Animals were maintained on a 12-h light/dark cycle at $22 \pm 1{ }^{\circ} \mathrm{C}$ and $55 \pm 10 \%$ relative humidity.

\subsection{Development of pulmonary hypertension}

The model of pulmonary hypertensive rats following treatment of rats with monocrotaline (MCT) was used (Kodavanti et al., 1998). A single intraperitoneal injection of MCT (Sigma Chemical Co., $60 \mathrm{mg} / \mathrm{kg}$ ) was administered to each rat. Fourteen days after MCT treatment CAP exposure was conducted.

\subsection{Exposure design}

We had closely followed the ambient particle concentration using a dust storm forecast system of the Taiwan Environmental Protection Administration (EPA) in order to conduct experiments during the peak of a dust storm because dust storms move quickly and the nose-only exposure system used in our experiment allowed only a short period of exposure. The ambient $\mathrm{PM}_{10}$ concentration at Chung-Li was around $30 \mu \mathrm{g} / \mathrm{m}^{3}$ in March of 2002. When the $\mathrm{PM}_{10}$ monitored at a nearby station was greater than $100 \mu \mathrm{g} / \mathrm{m}^{3}$, we began animal exposure. Two groups of animals were successfully exposed to CAPs during an Asian dust storm. Each exposure group was originally designed for $6 \mathrm{~h}$ of CAP exposure. The first group $(N=4)$ was exposed for $6 \mathrm{~h}$ of CAPs from 9:00 PM on March 18 to 3:00 AM on March 19 , 2002. However, the second group $(N=4)$ was exposed for only $4.5 \mathrm{~h}$ from 3:00 AM to 7:30 AM on March 19. The exposure was terminated early because of the development of respiratory distress in the exposed animals. The control group consisted of one animal exposed to room air for $6 \mathrm{~h}$ with the first exposure group and three animals exposed to room air for $4.5 \mathrm{~h}$ with the second exposure group.

The methodology for exposing pulmonary hypertensive rats with concentrated PM has been described in our previous study (Cheng et al., 2003). Briefly, ambient particles from the Chung-Li area, a suburb of Taipei, Taiwan, were concentrated using a modified ultrafine particle concentrator developed by Sioutas et al. (1999). The particle concentrator used virtual impactor technology in which $110 \mathrm{~L} / \mathrm{min}$ flow was channeled through a saturator, cooler, impactor, and diffusion dryer to generate concentrated particles with aerodynamic diameters between 0.01 and $2.5 \mu \mathrm{m}$. The concentrator output was about $10 \mathrm{~L} / \mathrm{min}$ at a negative pressure of about $2 \mathrm{~mm} \mathrm{Hg}$. Air containing concentrated particles was directed into the nose-only exposure chambers. Average CAP mass concentration during exposure was calculated from the mass collected on filters, and the elemental composition of the particles was determined using X-ray fluorescence. The first group exposed between 9:00 PM on March 18 and 3:00 AM on March 19 was defined as a low-exposure group with a mean CAP concentration of $315.6 \mu \mathrm{g} / \mathrm{m}^{3}$. The second group exposed between 3:00 AM and 7:30 AM on March 19 was defined as a high-exposure group with a mean CAP concentration of $684.5 \mu \mathrm{g} / \mathrm{m}^{3}$. The average $\mathrm{PM}_{10}$ monitored at a nearby EPA station during the first and second periods of exposure was 105.8 and $126.5 \mu \mathrm{g} / \mathrm{m}^{3}$, respectively. In the low-exposure group, the mean elemental concentration for silica was $53.3 \mu \mathrm{g} / \mathrm{m}^{3}$, for aluminum $14.0 \mu \mathrm{g} / \mathrm{m}^{3}$, for sulfur $6.25 \mu \mathrm{g} / \mathrm{m}^{3}$, for calcium $6.1 \mu \mathrm{g} / \mathrm{m}^{3}$, for potassium $3.1 \mu \mathrm{g} / \mathrm{m}^{3}$, for magnesium $2.7 \mu \mathrm{g} / \mathrm{m}^{3}$, for iron $2.1 \mu \mathrm{g} / \mathrm{m}^{3}$, for arsenic $2.1 \mu \mathrm{g} / \mathrm{m}^{3}$, for nickel $0.09 \mu \mathrm{g} / \mathrm{m}^{3}$, for tungsten $0.9 \mu \mathrm{g} / \mathrm{m}^{3}$, and for vanadium $0.2 \mu \mathrm{g} / \mathrm{m}^{3}$. The mean elemental concentration of the high-exposure group for silica was $41.6 \mu \mathrm{g} / \mathrm{m}^{3}$, for aluminum $10.7 \mu \mathrm{g} / \mathrm{m}^{3}$, for potassium $3.6 \mu \mathrm{g} / \mathrm{m}^{3}$, for arsenic $2.9 \mu \mathrm{g} / \mathrm{m}^{3}$, for magnesium $1.2 \mu \mathrm{g} / \mathrm{m}^{3}$, for calcium $1.7 \mu \mathrm{g} / \mathrm{m}^{3}$, for tungsten $1.4 \mu \mathrm{g} / \mathrm{m}^{3}$, and for vanadium $0.1 \mu \mathrm{g} / \mathrm{m}^{3}$.

In addition, concentrations of water-soluble ions and the carbonaceous content of $\mathrm{PM}_{2.5}$ and criteria air pollutants were also monitored at a Taiwan EPA supersite and a regular monitoring station, respectively. Both stations were located in Hsin-Chuang, $40 \mathrm{~km}$ north of Chung-Li. These data were used to describe the characteristics of air pollutants during the dust storm (Table 1). Ambient carbon particulate Monitor 5400 (Rupprecht and Patashnick Co., Inc.) was used to determine the concentrations of organic and elemental carbons in $\mathrm{PM}_{2.5}$. Ambient particulate nitrate Monitor 8400N (Rupprecht and Patashnick Co., Inc.) and ambient particulate sulfate Monitor 8400 S (Rupprecht and Patashnick Co., Inc.) were used to determine the concentrations of nitrate and sulfate. During the dust storm, the average concentrations of pollutants were as 
Table 1

Concentrations of $\mathrm{PM}_{10}, \mathrm{PM}_{2.5}$, water-soluble ions and carbonaceous content in $\mathrm{PM}_{2.5}$, and criteria air pollutants during the periods with and without Asian dust storms in March 2002

\begin{tabular}{|c|c|c|}
\hline \multirow[t]{2}{*}{ Pollutants } & \multicolumn{2}{|l|}{ Mean (SD) } \\
\hline & Dust storm & Without dust storm \\
\hline $\mathrm{PM}_{10}\left(\mu \mathrm{g} / \mathrm{m}^{3}\right)^{\mathrm{a}}$ & $103(34)$ & $54(37)$ \\
\hline $\mathrm{PM}_{2.5}\left(\mu \mathrm{g} / \mathrm{m}^{3}\right)^{\mathrm{a}}$ & $39(11)$ & $31(19)$ \\
\hline Organic carbon $\left(\mu \mathrm{g} / \mathrm{m}^{3}\right)^{\mathrm{a}}$ & $5.9(1.9)$ & $6.9(4.1)$ \\
\hline Elemental carbon $\left(\mu \mathrm{g} / \mathrm{m}^{3}\right)^{\mathrm{a}}$ & $2.0(1.2)$ & $2.2(2.3)$ \\
\hline Sulfate $\left(\mu \mathrm{g} / \mathrm{m}^{3}\right)^{\mathrm{a}}$ & $8.4(3.9)$ & $6.2(4.3)$ \\
\hline Nitrate $\left(\mu \mathrm{g} / \mathrm{m}^{3}\right)^{\mathrm{a}}$ & $1.9(1.0)$ & $2.7(3.0)$ \\
\hline $\mathrm{SO}_{2}(\mathrm{ppb})^{\mathrm{b}}$ & $4(3)$ & $6(4)$ \\
\hline $\mathrm{NO}_{2}(\mathrm{ppb})^{\mathrm{b}}$ & $23(11)$ & $28(15)$ \\
\hline
\end{tabular}

${ }^{\mathrm{a}}$ Monitored at a Taiwan EPA supersite in Hsin-Chuang.

${ }^{\mathrm{b}}$ Monitored at a Taiwan EPA monitoring station in Hsin-Chuang.

follows: $\mathrm{PM}_{10}, 103 \mu \mathrm{g} / \mathrm{m}^{3} ; \mathrm{PM}_{2.5}, 39 \mu \mathrm{g} / \mathrm{m}^{3}$; organic carbon, $5.9 \mu \mathrm{g} / \mathrm{m}^{3}$; elemental carbon, $2.0 \mu \mathrm{g} / \mathrm{m}^{3}$; sulfate, $8.4 \mu \mathrm{g} / \mathrm{m}^{3}$; nitrate, $1.9 \mu \mathrm{g} / \mathrm{m}^{3} ; \mathrm{SO}_{2}, 4 \mathrm{ppb} ; \mathrm{NO}_{2}, 23 \mathrm{ppb}$. In comparison, in March, excluding the period of dust storms, the average concentrations of pollutants were as follows: $\mathrm{PM}_{10}, 54 \mu \mathrm{g} / \mathrm{m}^{3} ; \mathrm{PM}_{2.5}, 31 \mu \mathrm{g} / \mathrm{m}^{3}$; organic carbon, $6.9 \mu \mathrm{g} / \mathrm{m}^{3}$; elemental carbon, $2.2 \mu \mathrm{g} / \mathrm{m}^{3}$; sulfate, $6.2 \mu \mathrm{g} / \mathrm{m}^{3}$; nitrate, $2.7 \mu \mathrm{g} / \mathrm{m}^{3} ; \mathrm{SO}_{2}, 6 \mathrm{ppb} ; \mathrm{NO}_{2}, 28 \mathrm{ppb}$. Finally, the wind speed was $2.8 \mathrm{~m} / \mathrm{s}$ during the dust storm period and $1.6 \mathrm{~m} / \mathrm{s}$ during nondust storm periods.

\subsection{Blood cells in peripheral blood}

Rats were sacrificed $36 \mathrm{~h}$ after exposure. Several peripheral blood parameters, including those associated with red blood cells, white blood cells, hemoglobin, the hematocrit, and platelets, were determined by a Sysmex KX-21 autoanalyzer (TOA Medical Electronics Co.).

\subsection{Bronchoalveolar lavage fluid analysis}

BAL fluid was collected by a washing of the airway with a phosphate-buffered saline solution ( $\mathrm{pH}$ of 7.4, $28 \mathrm{~mL} / \mathrm{kg}$ body wt.) five times. Lavage fluid was used to determine the total number of cells and cell differential counts. Macrophages, lymphocytes, neutrophils, eosinophils, and basophils were counted under light microscopy (200 cells/slide). The remaining lavage fluid was used for the analysis of total protein and $\mathrm{LDH}$ activity. LDH activity was determined with an autoanalyzer at the National Taiwan University Hospital. Total protein was determined using a total protein assay kit (Bio-Rad). Cytokine interleukin-6 (IL-6) protein was also determined using a specific ELISA kit (BioSource).

\subsection{Statistical analysis}

The SAS software package, version 8, was used for statistical analysis. The Student's $t$ test was used to compare the effects of high and low CAP exposed groups with a control group on various indices of inflammation markers in BAL and peripheral blood. Linear regression analysis was used to test for a trend in the inflammation markers in the control and low- and high-exposure groups. The type I error rate was set at 0.05 for significance.

\section{Results}

In the peripheral blood obtained $36 \mathrm{~h}$ after CAP exposure, the number of white blood cells in the lowexposure group was significantly higher than that in the control group exposed to room air $\left(9.6 \times 10^{3} / \mu \mathrm{L}\right.$ vs. $\left.6.0 \times 10^{3} / \mu \mathrm{L}, P<0.05\right)$. A similar finding was determined for the high-exposure group $\left(12.3 \times 10^{3} / \mu \mathrm{L}\right.$ vs. $\left.6.0 \times 10^{3} / \mu \mathrm{L}, P<0.05\right)$. In addition, there was a doseresponse relationship between CAP exposure and white blood cell count in peripheral blood $(P<0.05$, test for trend). However, there was no difference between the exposure and control groups in terms of other blood parameters (Table 2).

In BAL fluid, the high-exposure group had the highest total cells, followed by the low-exposure group, and, lastly, the control group (365.3, 207.3, $92 \times 10^{4}$, respectively) (Table 3). The number of total cells presented in BAL fluid increased with CAP levels $(P<0.05$, test for trend $)$. An increase in the percentage of neutrophils after CAP exposure was also observed (8.7, 26.5, and $39 \%, P<0.05$, test for trend). However, there was no increase for macrophages and lymphocytes after exposure.

For rats that were exposed to CAPs during the Asian dust storm, total protein levels in BAL fluid increased with increasing exposure, with the control group having the lowest level of total protein, the low-exposure group on intermediate level, and the high-exposure group the highest level of total protein $(2.1 \pm 0.4,2.2 \pm 0.6$,

Table 2

Blood parameters in peripheral blood after CAP exposure during a dust storm

\begin{tabular}{lccc}
\hline & $\begin{array}{l}\text { Controls } \\
(n=4)\end{array}$ & $\begin{array}{c}\text { Low-exposure } \\
\text { group }(n=4)\end{array}$ & $\begin{array}{c}\text { High-exposure } \\
\text { group }(n=4)\end{array}$ \\
\hline $\begin{array}{l}\text { White blood cells } \\
\left(10^{3} / \mu \mathrm{L}\right)\end{array}$ & $6.0 \pm 1.6$ & $9.6 \pm 1.0^{\mathrm{a}}$ & $12.3 \pm 1.0^{\mathrm{a}, \mathrm{b}, \mathrm{c}}$ \\
$\begin{array}{l}\text { Red blood cells } \\
\left(10^{6} / \mu \mathrm{L}\right)\end{array}$ & $5.6 \pm 0.6$ & $6.5 \pm 0.5$ & $6.7 \pm 1.6$ \\
$\begin{array}{l}\text { Hemoglobin } \\
(\mathrm{g} / \mathrm{dL})\end{array}$ & $10.9 \pm 0.8$ & $12.3 \pm 1.1$ & $12.6 \pm 3.4$ \\
$\begin{array}{l}\text { Hematocrit }(\%) \\
\text { Platelet }\left(10^{3} / \mu \mathrm{L}\right)\end{array}$ & $32.6 \pm 2.5$ & $36.8 \pm 2.9$ & $38.5 \pm 9.8$ \\
\hline $\begin{array}{l}{ }^{\mathrm{a}} \text { Comparison with control group, } P<0.05 . \\
{ }_{\mathrm{b}}{ } P<0.05, \text { test for trend. } \\
{ }^{\mathrm{c}} \text { Comparison between high- and low-exposure groups, } P<0.05 .\end{array}$
\end{tabular}


Table 3

Cell number and cell differential in BAL after CAP exposure during a dust storm

\begin{tabular}{lccc}
\hline & $\begin{array}{l}\text { Controls } \\
(n=4)\end{array}$ & $\begin{array}{l}\text { Low-exposure } \\
\text { group }(n=4)\end{array}$ & $\begin{array}{c}\text { High-exposure } \\
\text { group }(n=4)\end{array}$ \\
\hline Total cell $\left(\times 10^{4}\right)$ & $92 \pm 41.4$ & $207.3 \pm 51.9^{\mathrm{a}}$ & $365.3 \pm 36.2^{\mathrm{a}, \mathrm{b}, \mathrm{c}}$ \\
Macrophage $(\%)$ & $56.4 \pm 23.8$ & $54.8 \pm 8.3$ & $40.6 \pm 5.2$ \\
Lymphocyte $(\%)$ & $18.8 \pm 6.8$ & $15.1 \pm 1.7$ & $17.4 \pm 5.5$ \\
Neutrophil $(\%)$ & $8.7 \pm 2.4$ & $26.5 \pm 10.5^{\mathrm{a}}$ & $39 \pm 3.3^{\mathrm{a}, \mathrm{b}, \mathrm{c}}$ \\
Eosinophil $(\%)$ & $3.5 \pm 2.5$ & $2.1 \pm 1.2$ & $3.3 \pm 2.8$ \\
Basophil $(\%)$ & $0.3 \pm 0.3$ & $1.4 \pm 0.6$ & $0.3 \pm 0.3$ \\
\hline
\end{tabular}

${ }^{\text {a }}$ Comparison with control group, $P<0.05$.

${ }^{\mathrm{b}} P<0.05$, test for trend.

${ }^{\mathrm{c}}$ Comparison between high- and low-exposure groups, $P<0.05$.

$3.5 \pm 0.9 \mathrm{mg} / \mathrm{dL}$, respectively; $P<0.05$, test for trend) (Fig. 1a). A similar increase was also observed for $\mathrm{LDH}$ activity for the control group, the low-exposure group, and the high-exposure group $(10.3 \pm 1.9,26.3 \pm 7.4$, $81.3 \pm 39.3 \mathrm{U} / \mathrm{L}$, respectively; $P<0.05$, test for trend) (Fig. 1b). The concentration of cytokine IL-6 protein in BAL fluid also increased after CAP exposure. A significant increasing trend was observed from the control group to the low-exposure group and to the high-exposure group $(33.5 \pm 7.5,165.1 \pm 117.2,273.6 \pm$ $62.8 \mathrm{pg} / \mathrm{mL}$, respectively; $P<0.05$, test for trend) (Fig. 1c).

\section{Discussion}

Marked pulmonary inflammation and injury accompanying an increased white blood cell count in peripheral blood were observed in MCT-treated pulmonary hypertensive rats after short-term exposure to CAPs during an Asian dust storm.

Previous studies have shown that an increased percentage of neutrophils and total cells in BAL in animals exposed to CAPs (Clarke et al., 2000; Gordon et al., 1998). In the same studies, indications of pulmonary injury including protein and LDH activity in BAL were also observed. Our study further demonstrated that CAPs might cause lung inflammation and injury during the dust storm.

The mean mass concentration of $\mathrm{PM}_{10}$ during this dust storm in the Chung-Li area was 3 -fold higher than that during the periods without dust storms. Further, the mass concentration of silica during this dust storm was 10 -fold higher than that during the periods without dust storms presented in our previous study (Cheng et al., 2003). Importantly, we also observed a doseresponse relationship between CAPs and lung inflammation and injury. These suggest that dust storm particles played a major role in lung inflammation and injuries in the present study.
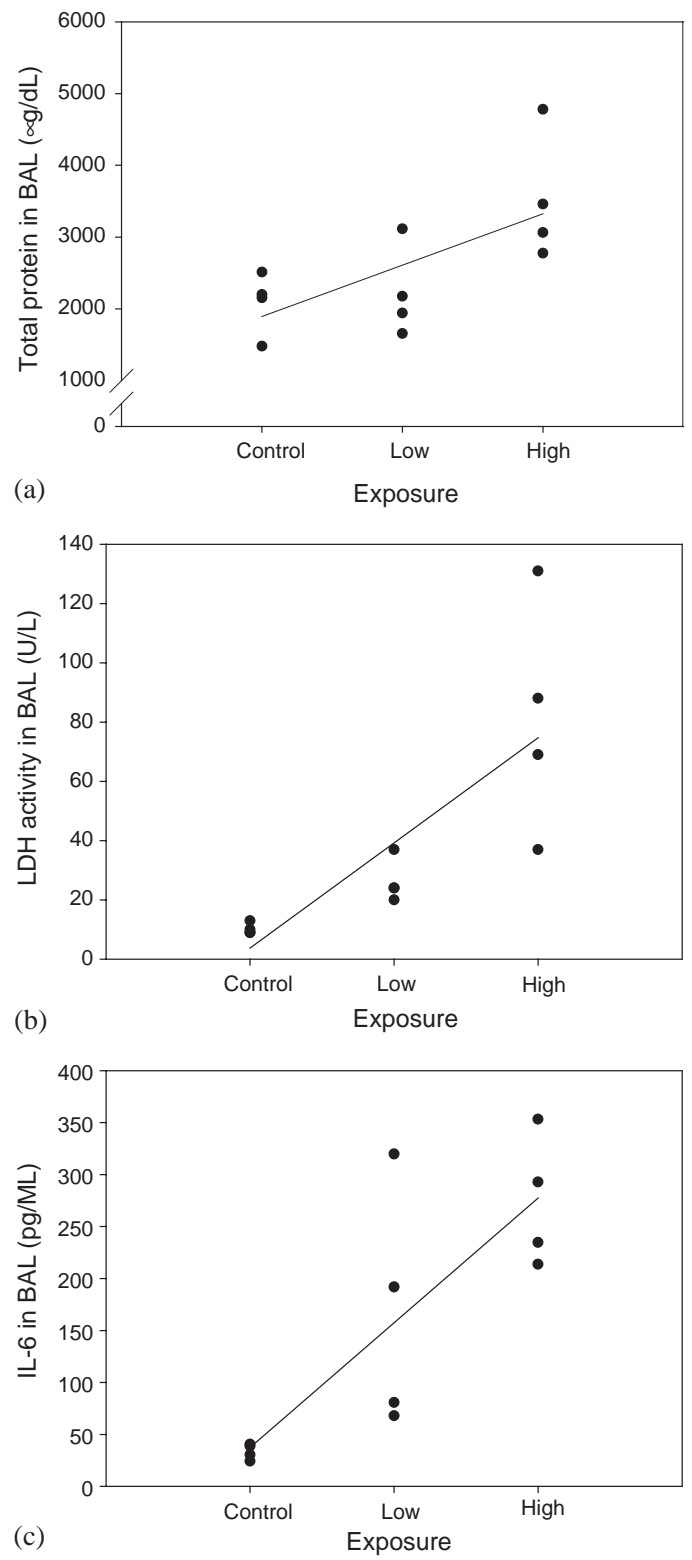

Fig. 1. (a) Total protein, (b) LDH activity, and (c) IL-6 in BAL in control and low- and high-exposure groups. $P<0.05$, test for trend for total protein, LDH activity, and IL-6.

The exact mechanism through which dust particles cause lung inflammation and injuries remains unclear. One possible explanation is an increase in the concentration of fine or ultrafine particles during Asian dust events. Particles less than $2.5 \mu \mathrm{m}$ are believed to have significant impact on human health. According to a previous report, one-third to one-half of the dust mass that arrives in the United States as part of the Saharan dust clouds is smaller than $\mathrm{PM}_{2.5}$ (Taylor, 2002). Therefore, it is very likely that dust storms may be composed of a large number of fine or ultrafine particles. The other explanation is the component of 
the dust storm particles. These particles have traveled through many industrial areas in China. Thus, hazardous compounds may be adsorbed onto the surface of the particles. It appeared that the concentrations of $\mathrm{SO}_{2}$, $\mathrm{NO}_{2}$, elemental carbon, and organic carbon were lower, while the mean concentrations of sulfate of $\mathrm{PM}_{2.5}$ were higher during the dust storm compared to those values measured during the periods without dust storms. Thus, the contribution from local sources on lung effect was limited. It is likely that sulfate may be formed on PM during the long-distance traveling before the dust events hit Taiwan. Sulfate has been associated with increased neutrophils in BAL in exposed humans (Huang et al., 2003). The third explanation is that microorganisms on $\mathrm{PM}$, such as fungi and bacteria, may cause pulmonary inflammation. Endotoxin of bacteria is known to cause inflammation through the reaction of macrophages (Monn and Becker, 1999). Further studies are needed to elucidate the effect of composition, number concentration, and size distribution of PM of Asian dust storm.

This study also demonstrated that exposure to CAPs during an Asian dust storm can induce an increase in proinflammatory cytokine IL-6 protein in BAL in pulmonary hypertensive rats. Expression of IL-6 has been reported in human epithelial cells exposed to ROFA (Carter et al., 1997). In animal studies, rats exposed to urban particles and ozone have been observed to develop extensive IL-6 release (Adamson et al., 1999). The expression of IL-6 in BAL suggests that CAPs cause pulmonary inflammation in part by inducing the proinflammatory response in lung (Monn and Becker, 1999).

In this study, an increase of white blood cells in peripheral blood was observed in CAPs-exposed rats during an Asian dust event. This response may reflect systemic stress from the exposure. Prior studies have reported an association between increased neutrophils in peripheral blood and CAPs in rats (Kodavanti et al., 1999) and that the blood leukocyte count in ROFAexposed rats can also be significantly elevated compared to controls (Gardner et al., 2000). However, no change in the mean white blood count from CAPs exposure has been observed in canines (Clarke et al., 2000). Further studies are needed to elucidate the exact mechanisms underlying PM-induced hematologic changes.

We conclude that Asian dust storm particles may cause pulmonary inflammation and injury and possibly a systemic response. We do believe that with such a high concentration of CAP exposure, some effects would be observed. However, our results demonstrated that dust storm particles, which are different from the products of the automobile combustion process, may also cause adverse effect on diseased animals. Since Asian dust storms have already become an important environmental issue not only in China but also in neighboring countries, including Korea, Japan, and Taiwan, the particle toxicity of Asian dust storms warrants further study.

\section{Acknowledgments}

This study was funded by the EPA of Taiwan (EPA-91-FA11-03-91DF02).

\section{References}

Adamson, I., Vincent, R., Bjarnason, S.G., 1999. Cell injury and interstitial inflammation in rat lung after inhalation of ozone and urban particulates. Am. J. Respir. Cell. Mol. Biol. 20, 1067-1072.

Carter, J.D., Ghio, A.J., Samet, J.M., Develin, R.B., 1997. Cytokine production by human airway epithelial cells after exposure to an air pollution particle is metal-dependent. Toxicol. Appl. Pharmacol. 146, 180-188.

Cheng, T.J., Hwang, J.S., Wang, P.Y., Tsai, C.F., Chen, C.Y., Lin, S.H., Chan, C.C., 2003. Effects of concentrated ambient particles on heart rate and blood pressure in pulmonary hypertensive rats. Environ. Health Perspect. 111, 147-150.

Clarke, R.W., Coull, B., Reinisch, U., Catalano, P., Killingsworth, C.R., Koutrakis, P., Kavouras, I., Murthy, G.G.K., Lawrence, J., Lovett, E., Wolfson, M., Verrier, R.L., Godleski, J.J., 2000. Inhaled concentrated ambient particles are associated with hematologic and bronchoalveolar lavage changes in canines. Environ. Health Perspect. 108, 1179-1187.

Dreher, K., Jaskot, R., Lehmann, J., Richards, J., McGee, J., Ghio, A., Costa, D., 1997. Soluble transition metals mediate residual oil fly ash induced acute injury. J. Toxicol. Environ. Health 50, 285-305.

Gardner, S., Lehmann, J., Costa, D., 2000. Oil fly ash-induced elevation of plasma fibrinogen levels in rats. Toxicol. Sci. 56, 175-180.

Gordon, T., Nadziejko, C., Schlesinger, R., Chen, L.C., 1998. Pulmonary and cardiovascular effects of acute exposure to concentrated ambient particulate matter in rats. Toxicol. Lett. 96-97, 285-288

Huang, Y.C., Ghio, A.J., Stonechuerner, J., McGee, J., Carter, J.D., Grambow, S.C., Devlin, R.B., 2003. The role of soluble components in ambient fine particles-induced changes in human lungs and blood. Inhalation Toxcicol. 15, 327-342.

Kodavanti, U.P., Costa, D.L., Bromnerg, P.A., 1998. Rodent models of cardiovascular disease: their potential applicability in studies of air pollutant susceptibility. Environ. Health Perspect. 106 (Suppl. 1), 111-130.

Kodavanti, U.P., Jackson, M.C., Ledbetter, A.D., Richards, J.R., Gardner, S.Y., Watkinson, .W.P., Costa, D.L., 1999. Lung injury from intratracheal and inhalation exposures to residual oil fly ash in a rat model of monocrotalineinduced pulmonary hypertension. Toxicol. Environ. Health A 57, 543-563.

Kwon, H.J., Cho, S.H., Chun, Y., Lagarde, F., Pershagen, G., 2002. Effects of the Asian dust events on daily mortality in Seoul, Korea. Environ. Res. 90, 1-5.

Monn, C., Becker, S., 1999. Cytotoxicity and induction of proinflammatory cytokines from human monocytes exposed to fine $\left(\mathrm{PM}_{2.5}\right)$ and coarse particles $\left(\mathrm{PM}_{10-2.5}\right)$ in outdoor and indoor air. Toxicol. Appl. Pharmacol. 155, 242-252. 
Pope III, C.A., Dockery, D.W., 1999. Epidemiology of particle effects. In: Holgate, S.T., Samet, J.M., Koren, H.S., Maynard, R.L. (Eds.), Air Pollution and Health. Academic Press, London, pp. 673-705.

Pope III, C.A., Burnett, R.T., Thun, M.J., Calle, E.E., Krewski, D., Ito, K., 2002. Lung cancer, cardiopulmonary mortality, and longterm exposure to fine particulate air pollution. J. Am. Med. Assoc. 287, 1132-1141.
Samet, J.M., Dominici, F., Curriero, F.C., Coursac, I., Zeger, S.L., 2000. Fine particulate air pollution and mortality in 20 US cities, 1987-1994. N. Engl. J. Med. 343, 1742-1749.

Sioutas, C., Kim, S., Chang, M., 1999. Development and evaluation of a prototype ultra-fine particle concentrator. J. Aerosol Med. 30, 1001-1017.

Taylor, D.A., 2002. Dust in the wind. Environ. Health Perspect. 110, A80-A87. 